\title{
Stanovení koliformních bakterií a Escherichia coli na chromogenním médiu
}

\section{DANA BAUDIŠOVÁ}

Klíčová slova: koliformní bakterie - Escherichia coli - chromogenní agar - pitná voda

\section{SOUHRN}

Tento př́ispěvek předkládá praktické zkušenosti s chromogenním médiem CCA, které se podle novely normy ČSN EN ISO 9308-1 použivá ke stanovení koliformních bakterií a E. coli ve vodách s nízkým obsahem doprovodné mikroflóry. Jsou uvedeny vybrané charakteristiky metody a jsou diskutovány hlavní problémy s jeho využitím ve vodohospodářské praxi.

\section{ÚVOD}

V dubnu 2015 došlo v souvislosti s novelizací normy ČSN EN ISO 9308-1 [1] k významné změně metody stanovení koliformních bakterií a Escherichia coli. Jedná se o vysoce citlivou metodu, vhodnou pouze pro vody s nízkým obsahem doprovodné mikroflóry, především tedy pro dezinfikované vody (upravená pitná voda, bazény). U ostatních typů vod (mělké soukromé studny, povrchové vody, zejména stojaté apod.) je její využití sporné, především pro vysoký nárůst doprovodné mikroflóry. Tato metoda byla $v$ minulých letech testována pro prípadné použití v prírodních koupacích vodách a vzhledem k nízké selektivitě (viz dále) byla vyhodnocena pro tento typ vod jako nevyhovující [2].

Koliformní bakterie jsou podle této normy skupina gramnegativních tyčinek netvorících spory s negativním cytochromoxidázovým testem, které tvoři za aerobních podmínek kolonie během 24 hodin na selektivním diferenciačním médiu při kultivační teplotě $(36 \pm 2)^{\circ} \mathrm{C}$. Koliformní bakterie vykazují aktivitu $\boldsymbol{\beta}$-D-galaktosidázy a E. coli je ta koliformní bakterie, která zároveň vykazuje aktivitu $\boldsymbol{\beta}$-D-glukuronidázy. Významná je změna „detekčního systému“ koliformních bakterií a E. coli oproti dřivější metodě založené na fermentaci laktózy (koliformní bakterie) a tvorbě indolu (E. coli). Aktivitu $\beta$-D-galaktosidázy vykazuje mnohem širší spektrum bakterií (tento enzym štěpí laktózu na galaktózu a glukózu, která dále může a nemusí být fermentována na kyselé produkty); podrobně jsou biochemické vlastnosti jednotlivých druhů bakterií z čeledi Enterobacteriaceae uvedeny v Bergey's Manual of Determinative Microbiology [3]. Počet koliformních bakterií detekovaných na chromogenním médiu tak bývá významně vyšší, než byl jejich záchyt na dřive používaném laktózovém TTC agaru s tergitolem, a výsledky proto nekorelují. Naproti tomu stanovení E. coli pomocí enzymu $\beta$-D-glukuronidázy je mnohem specifičtější než dříve používaný indol test (test na $\beta$-D-glukuronidázu byl $\vee$ dřívější verzi normy pouze nepovinný a prakticky se nepoužíval), takže výsledky stanovení E. coli na chromogenním médiu budou výrazně spolehlivější.

\section{METODIKA}

Koliformní bakterie a E. coli se stanovují membránovou filtrací (většinou se filtruje objem $100 \mathrm{ml}$ vzorku), membránové filtry mají porozitu 0,45 $\mu \mathrm{m}$. Filtr se umístí na chromogenní médium (Chromogenic-Coliform Agar) a kultivuje se (21 \pm 3 ) hodiny při $(36 \pm 2)^{\circ} \mathrm{C}$. Složení Chromogenic-Coliform Agaru (dále CCA) je uvedeno v tabulce 1. CCA je běžně komerčně dostupný. Príprava CCA je velmi jednoduchá, naváží se príslušné množství prášku, resp. granulí, a rozpustí se $\checkmark$ destilované vodě. Nepřidávají se žádné další prídavky. Nesmí se autoklávovat. Po zchlazení na $45-50^{\circ} \mathrm{C}$ se agarové médium sterilně rozleje do Petriho misek. PH má být $6,8 \pm 0,2$ prí $25^{\circ} \mathrm{C}$ (podle našich zkušeností deklarované $\mathrm{pH}$ vždy sedělo, přesto je nutné u každé šarže provést kontrolu). Médium je velmi stálé, uvařené vydrží minimálně měsíc, jen je nutná ochrana před jeho vyschnutím. Kvalita média se testuje podle normy ČSN EN ISO 11133 [4].

Tabulka 1. Předepsanésložení CCA

Table 1. Prescribed composition of CCA

\begin{tabular}{lc}
\hline Enzymatický hydrolyzát kaseinu & $1,0 \mathrm{~g}$ \\
\hline Kvasničný extrakt & $2,0 \mathrm{~g}$ \\
\hline Chlorid sodný & $5,0 \mathrm{~g}$ \\
\hline Dihydrogenfosforečnan sodný * $2 \mathrm{H}_{2} \mathrm{O}$ & $2,2 \mathrm{~g}$ \\
\hline Hydrogenfosforečnan sodný & $2,7 \mathrm{~g}$ \\
\hline Pyrohroznan sodný & $1,0 \mathrm{~g}$ \\
\hline Sorbitol & $1,0 \mathrm{~g}$ \\
\hline Tryptofan & $1,0 \mathrm{~g}$ \\
\hline Tergitol 7 & $0,15 \mathrm{~g}$ \\
\hline 6-chlor-3-indoxyl- $\beta$-D-galaktopyranosid & $0,2 \mathrm{~g}$ \\
\hline Kyselina 5-brom-4-chlor-3-indoxyl- $\beta$-D-glukuronová & $0,1 \mathrm{~g}$ \\
\hline Isopropyl- $\beta$-D-thiogalaktopyranosid (IPTG) & $0,1 \mathrm{~g}$ \\
\hline Agar & $9-18 \mathrm{~g}$ \\
\hline Destilovanou vodou doplnit do & $1000 \mathrm{ml}$ \\
\hline
\end{tabular}




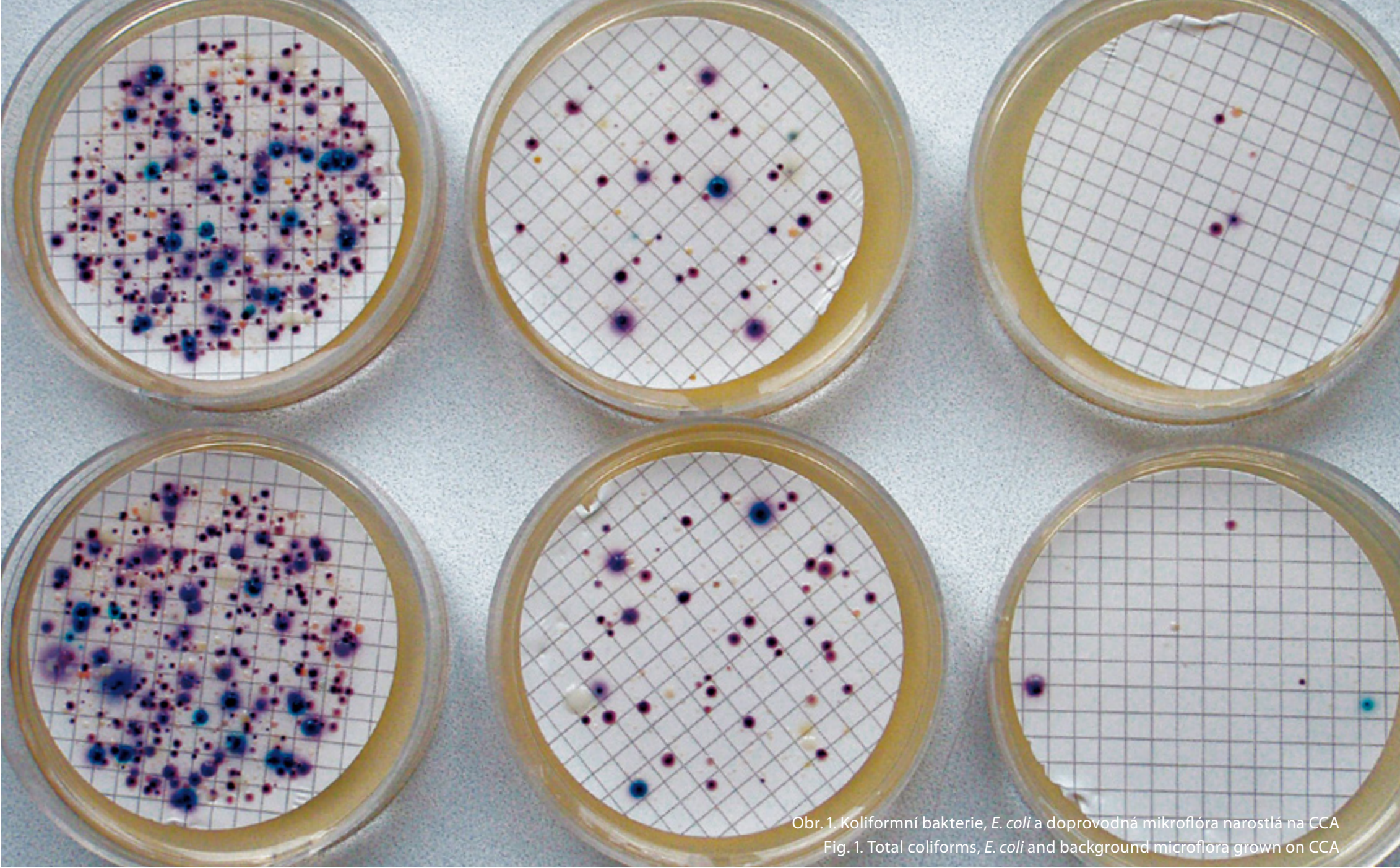

Koliformní bakterie rostou jako růžové až červené kolonie, E. coli jako tmavě modré až fialové kolonie (viz obr. 1). Doprovodná mikroflóra roste ve formě bezbarvých kolonií. Koliformní bakterie je nutné potvrdit pomocí oxidázového testu (koliformní bakterie jsou oxidáza negativní), který norma připouští provádět prrímo na membránovém filtru. Při případném přeočkování kolonií na neselektivní agar (pro další konfirmaci) je nutné kolonie pečlivě přečistit, aby se vždy pracovalo s čistou kulturou. Pro prípadnou další konfirmaci, resp. pro potvrzení aktivity enzymů $\beta$-D-galaktosidázy a $\beta$-D-glukuronidázy, Ize využít např. ONP test a GLR test (Erba, Lachema). Tyto testy Ize využít i pro stanovení citlivosti a specifičnosti príslušných reakcí na CCA. Při výpočtu výsledků je nutné mít na paměti důležitý fakt a to, že i E. coli patří mezi koliformní bakterie, a musí se tudiž do jejich počtu príčist:

- počet $E$. coli = počet modrých až modrofialových kolonií,

— počet koliformních bakterií = počet růžových až červených kolonií s negativním oxidázovým testem + počet modrých až modrofialových kolonií.

\section{VÝSLEDKY A DISKUSE}

Byly testovány desítky mírně organicky znečištěných vod, především za účelem získání charakteristik metody stanovení koliformních bakterií a E. coli na CCA. Přestože byly vzorky paralelně testovány na původním laktózovém TTC agaru s tergitolem (ČSN EN ISO 9308-1, 2001), výsledky nevykazovaly žádnou korelaci vzhledem k odlišnému principu obou médií. V tabulce 2 jsou uvedeny výsledky Zkoušení způsobilosti (ZZ) organizovaného ASLAB - OR-MB-1/15 (vzorky 1-5 jsou vzorky, které sloužily k ověření homogenity v laboratoři VúV TGM, v.v. i.), vztažná hodnota poté byla určena ze souboru všech účastníků $(K T J / m l, n=19)$.
Tabulka 2. Koliformní bakterie a E. coli na CCA a laktózovém agaru s Tergitolem 7 (Tergitol) pri OR-MB1/15

Table 2. Coliforms and E. coli on CCA and lactose agar with Tergitol 7 (Tergitol) at OR-MB1/15

\begin{tabular}{lcccc}
\hline & $\begin{array}{c}\text { CCA } \\
\text { E. coli }\end{array}$ & $\begin{array}{c}\text { CCA } \\
\text { koliformní }\end{array}$ & $\begin{array}{c}\text { Tergitol } \\
\text { E. coli }\end{array}$ & $\begin{array}{c}\text { Tergitol } \\
\text { koliformní }\end{array}$ \\
\hline 1 & 1 & 11,1 & 2,7 & 2,7 \\
\hline 2 & 1 & 12 & 4,8 & 4,8 \\
\hline 3 & 1 & 9,7 & 1,1 & 1,1 \\
\hline 4 & 1 & 9,1 & 3,6 & 3,6 \\
\hline 5 & 1 & 11,66 & 0,8 & 4 \\
\hline $\begin{array}{l}\text { Vztažná } \\
\text { hodnota }\end{array}$ & $\mathbf{1}$ & $\mathbf{1 2}$ & $\mathbf{2}$ & $\mathbf{4}$ \\
\hline
\end{tabular}

Z dalších charakteristik byly stanoveny produktivita (viz obr. 2), reprodukovatelnost v počitání a podíl falešně pozitivních a falešně negativních výsledků. Produktivita byla stanovena pomocí kmenů E. coli WDCM 00013 (CCM 3954) a Serratia rubidae (CCM 4684), která není uvedena v normě ČSN EN ISO 11133. Další kmeny, které jsou předepsány ve výše uvedené normě (Enterobacter aerogenes WDCM 00175, nebo Citrobacter freundii WDCM 00006), nebyly v době testování ještě k dispozici. 


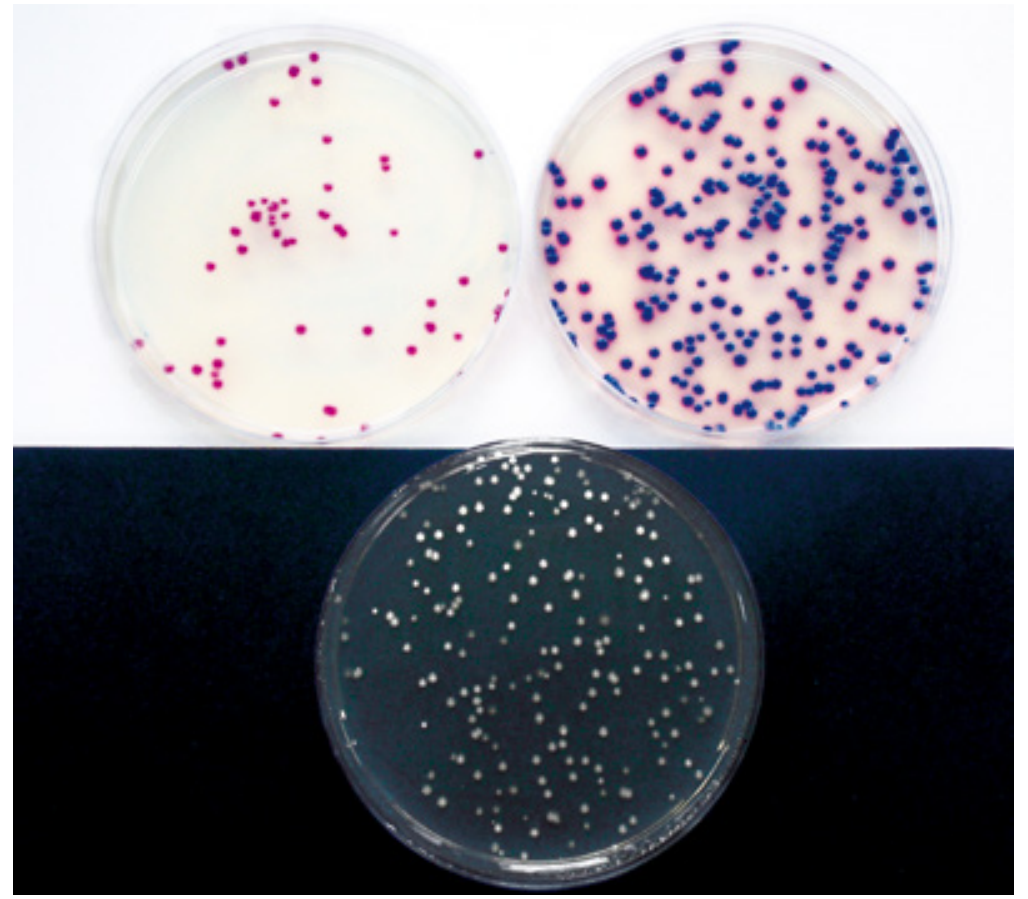

Obr. 2. Stanovení produktivity; vlevo nahoře Serratia rubidae na CCA, vpravo nahoře E. coli (WDCM 0013) na CCA a dole E. coli na neselektivním tryptózovém agaru

s kvasničným extraktem

Fig. 2. The productivity testing; left above Serratia rubidae on CCA, right above E. coli (WDCM 0013) on CCA, and down E. coli on nonselective tryptose agar with yeast extract

V informativní př́loze C normy ČSN EN ISO 9308-1 [1] je uvedena předepsaná minimální produktivita (výtěžnost) > 70 \%, a naše testování toto hodnotu významně překročilo. Produktivita pro kmen E. coli (CCM 3954) byla na CCA od firmy Merck 100 \%, na CCA od firmy Himedia 87,41\%; produktivita pro kmen Serratia rubidae, jakožto zástupce koliformních bakterií (CCM 4684), byla na CCA od firmy Merck 83,82 \% a na CCA od firmy Himedia $100 \%$.

Při reprodukovatelnosti v počítání (dva pracovníci, $n=18$ ) byl dosažen variační koeficient $9 \%$ pro E. coli a $10 \%$ pro ostatní koliformní bakterie, což je minimálně srovnatelné, spíše lepší, než tomu bylo u dříve používaného laktózového TTC agaru s Tergitolem 7.

Pomocí konfirmačních testů byl stanoven podíl falešně pozitivních a falešně negativních výsledků. Aktivita $\beta$-D-glukuronidázy byla ověřena pomocí fluorogenního substrátu (4-methylumbelliferyl- $\beta$-D-glukuronid), a v $98 \%$ se výsledky shodovaly $(n=50)$. Aktivita $\beta$-D-galaktosidázy byla konfirmována ONP testem. Vínové kolonie byly $100 \%$ konfirmovány jako $\beta$-D-galaktosidáza pozitivní (0 \% falešně pozitivních výsledků), u světlých kolonií byly zaznamenány falešně negativní výsledky v 9 \% (91% světlých kolonií bylo konfirmováno jako $\beta$-D-galaktosidáza negativní). Dále byly ověřovány oxidáza negativní kolonie testované prímo na membránovém filtru a po jejich přečištění byla negativní reakce potvrzena v $90 \%$.

Mezi hlavní výhody stanovení koliformních bakterií na CCA agaru patří skutečnost, že výsledky stanovení jak koliformních bakterií, tak E. coli jsou k dispozici již 24 hodin po naočkování a není třeba žádné další přeočkování kmenů na neselektivní agar. Zároveň norma připouští provedení oxidázového testu př́mo po přenesení membránového filtru na podložku nasycenou oxidázovým činidlem. Kromě tak pracného přeočkování a přečištování kolonií odpadne i následný prepočet na původní počet presumptivních kolonií, čímž se stanovení nejenom zrychlí, ale i zpřesní.

Nevýhodou stanovení je velký záchyt doprovodné mikroflóry, což znemožňuje využití k jinému než deklarovanému účelu (vody s nízkým obsahem doprovodné mikroflóry). Otázkou zůstává používání CCA u surových vod, které jsou sice nedezinfikované, nicméně není logické stanovovat koliformní bakterie a E. coli u surové a upravené vody na médiích o jiných biochemických principech.

Podle Bergey's Manual of Determinative Bacteriology, $9^{\text {th }}$ ed. [3] fermentuje laktózu ve více než 90 \% kmenů 25 druhů z čeledi Enterobacteriaceae (Butiaxella agrestis, pět druhů rodu Enterobacter, šest druhů rodu Erwinia, E. coli, tři druhy rodu Klebsiella, Kluyvera ascorbata a K. cryocrescens, Leclercia adecarboxylata, Rahnella aquatilis, Moellerella wisconsensis a dva druhy rodu Serratia). Další čtyři druhy fermentují laktózu v 79-89 \% a 18 druhů fermentuje laktózu v 25-75\% (včetně řady druhů rodu Citrobacter, Enterobacter, Serratia či Yersinia), ale jsou vždy $\beta$-D-galaktosidáza pozitivní. Dvacet druhů z čeledi Enterobacteriaceae (zahrnující rody Cedecea, Enterobacter, Erwinia, Escherichia, Hafnia, Salmonella (S. arizona), Shigella (S. sonnei), Serratia, Pantoea, Yersinia), které i když jsou v 90-100 \% kmenů $\beta$-D-galaktosidáza pozitivní, laktózu nefermentují (další druhy jsou $\beta$-D-galaktosidáza pozitivní variabilní a laktóza negativní). Výše uvedené skutečnosti skupinu koliformních bakterií posunují významně více od fekálního k obecnému znečištění a malé nedezinfikované studny prakticky nemají šanci limit pro koliformní bakterie $0 \mathrm{KTJ} / 100 \mathrm{ml}$ splnit.

Další malou, ale opticky výraznou skupinou jsou kolonie, které rostou jako tyrkysové, v některých prípadech velmi drobné (které většinou nevyrostou po přeočkování na neselektivní agar), v dalších prípadech rostou jako kolonie běžné velikosti (v průměru $1 \mathrm{~mm}$ ). Podle firemních materiálů zveřejněných na internetu (Merck, VWR Chemicals apod.) se jedná o další gramnegativní bakterie (doprovodná mikroflóra), $\beta$-D-glukuronidáza pozitivní. Podle našich praktických zkušeností šlo bud' o oxidáza pozitivní kmeny, nebo o $\beta$-D-galaktosidáza negativní E. coli, prípadně o intermediální kmeny z oblasti okolo rodů Shigella a Yersinia. $\checkmark$ některých př́padech byly konfirmovány i $\beta$-D-galaktosidáza pozitivní kmeny.

\section{ZÁVĚR}

Výhody (popř. nevýhody) využití CCA $\vee$ mikrobiologické praxi ukáže čas, nicméně už ted' se ukazuje, že jeho využití je vhodné pouze pro vody s nízkým obsahem doprovodné mikroflóry (především pro dezinfikované pitné, popř. bazénové vody). $V$ tomto prípadě se jedná o stanovení rychlé (během 24 hodin jsou k dispozici kompletní výsledky) a velmi citlivé. Využití CCA pro stanovení koliformních bakterií a E. coli v povrchových, popř. odpadních vodách Ize prakticky vyloučit, sporné je i jeho použití pro nedezinfikované malé studny, které v České republice nejsou legislativně ošetřeny.

\section{Autor}

RNDr. Dana Baudišová, Ph.D.

$凶$ dana_baudisova@vuv.cz

Výzkumný ústav vodohospodářský T. G. Masaryka, v. v. i., Praha

Příspěvek prošel lektorským řizením.

\section{Literatura}

[1] ČSN EN ISO 9308-1. Kvalita vod - Stanovení Escherichia coli a koliformnich bakterií - Část 1: Metoda membránových filtrů pro vody s nízkým obsahem doprovodné mikroflóry, 2015.

[2] BAUDIŠOVÁ, D. Metody stanovení Escherichia coli a intestinálních enterokoků v koupacích vodách. VTEI, roč. 55, č. 1, 2013, s. 5-7, přiloha Vodního hospodářství č. 2/2013. ISSN 0322-8916.

[3] HOLT, J.G., KRIEG, N.R., SNEATH, P. H.A., STALEY, J.T., and WILLIAMS, S.T. Facultative anaerobic Gram-negative rods. In: Bergey's Manual of Determinative Bacteriology, $9^{\text {th }}$ ed., Baltimore, 1994.

[4] ČSN EN ISO 11133. Mikrobiologie potravin, krmiv a vody - Př́prava, uchováváni a zkoušení výkonnosti kultivačnich půd, 2015. 

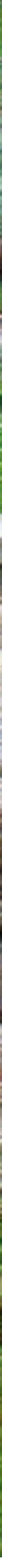

\section{DETECTION OF TOTAL COLIFORMS AND ESCHERICHIA COLION CHROMOGENIC MEDIUM}

\section{BAUDISOVA, D.}

TGM Water Research Institute, p. r. i.
Key words: total coliforms - Escherichia colichromogenic agar - drinking water

The aim of this study is introduction and practice of chromogenic medium CCA that is prescribed in the amendment of EN ISO 9308-1 standard for detection of Escherichia coli and coliform bacteria in waters with low bacteria background flora. Selected characteristics of the method are given, and the main problems dealing with its usage in water microbiology are discussed. 